Article

\title{
Accelerating Copper Leaching from Sulfide Ores in Acid-Nitrate-Chloride Media Using Agglomeration and Curing as Pretreatment
}

\author{
Pía C. Hernández ${ }^{1, *\left(\mathbb{D}, \text { Junior Dupont }^{1}, \text { Osvaldo O. Herreros }^{2} \text {, Yecid P. Jimenez }\right.}{ }^{1}$ \\ and Cynthia M. Torres ${ }^{3}$ \\ 1 Departamento de Ingeniería Química y Procesos de Minerales, Universidad de Antofagasta, Avda. \\ Angamos 601, 1240000 Antofagasta, Chile; junycool30@hotmail.com (J.D.); yecid.jimenez@uantof.cl (Y.P.J.) \\ 2 Departamento de Ingeniería en Minas, Universidad de Antofagasta, Avda. Angamos 601, \\ 1240000 Antofagasta, Chile; osvaldo.herreros@uantof.cl \\ 3 Departamento de Ingeniería Metalúrgica y Minas, Universidad Católica del Norte, Avda. Angamos 0610, \\ 1240000 Antofagasta, Chile; cynthia.torres@ucn.cl \\ * Correspondence: pia.hernandez@uantof.cl; Tel.: +56-55-2637313
}

Received: 29 March 2019; Accepted: 24 April 2019; Published: 25 April 2019

check for updates

\begin{abstract}
This work investigates the effect of an agglomeration and curing pretreatment on leaching of a copper sulfide ore, mainly chalcopyrite, using mini-columns in acid-nitrate-chloride media. Ten pretreatment tests were conducted to evaluate different variables, namely the addition of nitrate as $\mathrm{NaNO}_{3}$ (11.7 and $23.3 \mathrm{~kg} /$ ton), chloride as $\mathrm{NaCl}$ (2.1 and $19.8 \mathrm{~kg} /$ ton), curing time (20 and 30 days) and repose temperature $\left(25\right.$ and $\left.45{ }^{\circ} \mathrm{C}\right)$. The optimum copper extraction of $58.6 \%$ was achieved with the addition of $23.3 \mathrm{~kg}$ of $\mathrm{NaNO}_{3} / \mathrm{ton}, 19.8 \mathrm{~kg}$ of NaCl$/ \mathrm{ton}$, and after 30 days of curing at $45^{\circ} \mathrm{C}$. Under these pretreatment conditions, three samples of ore were leached in mini-columns. The studied parameters were temperature $\left(25\right.$ and $\left.45^{\circ} \mathrm{C}\right)$ and chloride concentration $(20$ and $40 \mathrm{~g} / \mathrm{L})$. The optimum copper extraction of $63.9 \%$ was obtained in the mini-column leaching test at $25^{\circ} \mathrm{C}$, with the use of $20 \mathrm{~g} / \mathrm{L}$ of chloride. A higher temperature $\left(45^{\circ} \mathrm{C}\right)$ and a higher chloride concentration $(40 \mathrm{~g} / \mathrm{L})$ negatively affected the extraction. The pretreatment stage had favorable effects, in terms of accelerating copper dissolution and improving leaching of copper sulfide ore in acid-nitrate-chloride media. Waste salts from caliche industry and waste brine from reverse osmosis can be used for providing the nitrate and chloride media.
\end{abstract}

Keywords: agglomeration; curing; copper sulfide; chalcopyrite; pretreatment; nitrate; chloride

\section{Introduction}

Industrial scale leaching of copper sulfide minerals like chalcopyrite $\left(\mathrm{CuFeS}_{2}\right)$ remains a metallurgical challenge. Chalcopyrite is mined worldwide [1], given the depths at which mining operations can now be carried out [2]. Copper sulfide is extracted by flotation, followed by the application of pyrometallurgical methods [3]. Leaching is an alternative metallurgical treatment for chalcopyrite, although chalcopyrite tends to form passive layers around particles during leaching, which results in a slow dissolution rate and low levels of copper extraction [4,5]. Many researchers have reported a higher percentage of copper extraction in acid-chloride media than acid-sulfate media to leach chalcopyrite [6-12]. A chloride-acid media promotes the formation of copper chloride-complexes [13] and iron chloride-complexes [14] that modify the redox potential (ORP), according Equations (1) and (2):

$$
\mathrm{Cu}^{2+}+\mathrm{Cl}^{-}+\mathrm{e}^{-} \rightarrow \mathrm{CuCl}(0.558 \mathrm{~V} \text { vs SHE })
$$




$$
\mathrm{Fe}^{3+}+\mathrm{Cl}^{-}+\mathrm{e}^{-} \rightarrow \mathrm{FeCl}^{+}(0.761 \mathrm{~V} \text { vs SHE })
$$

$\mathrm{Cu}(\mathrm{I})$ ions are stabilized in the solution by adding a new redox pair $\mathrm{Cu}(\mathrm{I}) / \mathrm{Cu}(\mathrm{II})$. Porous layer of sulfur is generated around the particle when chloride ions are present. This porous layer facilitates the diffusion of reagents that improves the leaching kinetics $[15,16]$. A chloride medium can be provided by seawater or processing brines, such as waste solution from reverse osmosis [17-22].

Oxidizing agents like oxygen [23], chlorine [24], ferric [25], cupric [26], nitrate [27], and others are required to dissolve chalcopyrite. Some researchers have tested nitric acid [28,29], and nitrite [30] to leach chalcopyrite, with good results in terms of copper extraction. Nitrogen species tend to be very strong oxidizing agents, and there are reports in the literature of obtaining high copper extraction with the use of nitrogen ions [31].

Mining of copper, lithium, nitrates and other minerals represents an important part of the Chilean economy [32]. Nitrate comes from the caliche industry concentrated in northern Chile. Nitrate salts, waste salts and intermediate processing solutions can be used in chalcopyrite leaching. Sokić et al. [27] studied leaching of chalcopyrite concentrate in acid-nitrate media and determined that increasing temperature and acid and nitrate concentrations increases copper extraction to over $75 \%$. Gok and Anderson [30] investigated the effect of addition of sodium nitrite in an acid medium during leaching of chalcopyrite and found that the extraction increased by $5 \%$ by using nitrite instead of nitrate, while other conditions remained the same. Shiers et al. [33] studied leaching chalcopyrite using different oxidants: hypochlorous acid, sodium chlorate and sodium nitrate with the addition of ferric ions (ferric sulfate, ferric nitrate and ferric chloride), and obtained a copper extraction of $92 \%$ in chloride-nitrate-ferric mixture, which proved favorable for chalcopyrite leaching at $50^{\circ} \mathrm{C}$. Tsogtkhankhai et al. [34] studied the kinetics of leaching copper with nitric acid, and with the estimation of the activation energy determined that temperature has a strong influence on the system. Castellón et al. [35] leached chalcopyrite concentrate in acid-nitrate media using seawater as a dissolvent and obtained a copper extraction of $97 \%$ in $24 \mathrm{~h}$ under the studied conditions $\left(\left[\mathrm{H}_{2} \mathrm{SO}_{4}\right]=\left[\mathrm{NaNO}_{3}\right]=0.5 \mathrm{M}\right)$ at $45^{\circ} \mathrm{C}$. The nitrogen species catalyzed (NSC) method uses sulfuric and nitric acids to leach sulfide minerals with the use of high pressure and temperature. The main advantage of this process is rapid extraction [31]. Many patents have been filed for leaching sulfide minerals in acid-nitrate media. Queneau and Prater [36] patented a process for leaching copper, iron, cobalt, silver and nickel sulfide in nitric acid. Arias [37] developed a process for leaching copper sulfide ore in heaps with an acid-nitrate media. Hard [38] patented a copper leaching process using sulfuric acid in the presence of nitrate ions. The optimal $\mathrm{pH}$ range $(0.5$ and 1.5), nitrate concentration (1-10\%) and ratio between $\mathrm{H}^{+}$and $\mathrm{NO}_{3}{ }^{-}$ions (ratio of 4 to 1 ) have been determined. Carnahan and Heinen [39] patented an in situ copper leaching process that uses a diluted acid medium and oxygen with nitrate ions that can come from nitric acid, an alkaline metal or ammonium nitrate. Lueders and Frankiewicz [40] patented a two-step leaching process in which sulfide ores are oxidized with nitrogen dioxide in an acid medium. Anderson et al. [41] patented a process to leach sulfide ores under conditions of temperature and pressure, using an acid medium with sodium nitrite. Hernández et al. [42] studied leaching chalcopyrite by agitation in acid-nitrate media at temperatures between 25 and $70{ }^{\circ} \mathrm{C}$, and compared the use of seawater to that of freshwater. Copper extraction close to $98 \%$ were obtained with three days of leaching at $70{ }^{\circ} \mathrm{C}$ in a seawater medium, with a high concentration of nitrate and acid $(1 \mathrm{M})$, and an $80 \%$ extraction was obtained with seven days of leaching at $45^{\circ} \mathrm{C}$.

Ore agglomeration and curing are carried out prior to leaching in heaps [43-45]. From the physical point of view, smaller particles of ore adhere to larger ones, resulting in relatively homogenous and stable material. This in turn results in a significant number of holes in piles, which is essential for adequate liquid and gas permeability of the agglomerated mineral bed [46,47]. The objective of curing is to attack the mineral chemically with concentrated sulfuric acid to dissolve most of the surface copper on particles, which creates a favorable condition for leaching. In this way, solutions with high levels of copper are obtained. Curing also solubilizes iron, contributing the ferric ions necessary to dissolve sulfides and inhibit the formation of colloidal silica to minimize silica passing to the leaching 
solutions [45]. Cerda et al. [48] studied the effect of a pretreatment stage at the laboratory level on dissolving a copper sulfide ore in a chloride-acid medium, and obtained a copper extraction of $93 \%$ leaching ore pretreated with $90 \mathrm{~kg} \mathrm{Cl}^{-} /$ton of ore and 40 days of repose at $50{ }^{\circ} \mathrm{C}$. A copper extraction of only $55 \%$ can be achieved without pretreatment, indicating the significant effect of the pretreatment stage. Bahamonde et al. [49] determined the positive effect of pretreating bornite and chalcopyrite in acid-chloride media to extract copper from these minerals. Taboada et al. [50] evaluated the effect of a pretreatment stage on leaching a mixed copper ore in mini-columns with the addition of ferric and ferrous ions in acid-chloride media and a repose period of 30 days. The process involved a 30-day cycle of pretreatment and 15 additional days of leaching (for a total of 45 days), resulting in 60 and $80 \%$ copper extraction, respectively. The addition of ferric ions in the pretreatment enhances copper extraction. Velásquez-Yévenes and Quezada-Reyes [21] studied leaching chalcopyrite in columns with a chloride medium, and a pretreatment with repose periods of 30, 50, 80 and 100 days. For the pretreatment, $5 \mathrm{~kg} \mathrm{H}_{2} \mathrm{SO}_{4} /$ ton and $60 \mathrm{~kg} /$ ton of seawater or waste brine were used, according to the test, with $0.5 \mathrm{~g} \mathrm{Cu}^{2+} / \mathrm{L}$. Intermittent irrigation began following the repose period. The authors found that the pretreatment improved extraction, which at room temperature and with 100 days of repose were 43 and $37 \%$, respectively with brine and seawater. Velásquez Yévenes et al. [51] studied the effect of adding chloride in agglomeration and a curing process to improve the copper extraction from sulfide ore in leaching by columns. The copper dissolution increased with the curing stage with chloride and acid addition.

The objective of this study is to determine the effects of copper sulfide pretreatment (agglomeration and curing) on leaching by percolation at a moderate temperature $\left(\leq 45^{\circ} \mathrm{C}\right)$ in acid-nitrate-chloride media in mini-columns. The pretreatment variables studied were the addition of sodium nitrate (11.7 and $23.3 \mathrm{~kg} /$ ton), and sodium chloride ( 2.1 and $19.8 \mathrm{~kg} / \mathrm{ton}$ ), curing time duration ( 20 and 30 days) and repose temperature $\left(25\right.$ and $\left.45^{\circ} \mathrm{C}\right)$. The leaching variables studied were the temperature of the system $\left(25\right.$ and $45^{\circ} \mathrm{C}$ ) and the chloride concentration $(20$ and $40 \mathrm{~g} / \mathrm{L})$.

\section{Materials and Methods}

\subsection{Ore Sample}

Copper sulfide from a mine in the Antofagasta Region was used in this work, with particle sizes under $9.53 \mathrm{~mm}$, and a $\mathrm{P}_{80}$ of $7.9 \mathrm{~mm}$. Atomic absorption spectrometry (AAS, Perkin-Elmer 2380, Perkin Elmer, Wellesley, MA, USA) showed that the chemical composition of the ore was $0.70 \%$ total $\mathrm{Cu}, 0.04 \%$ soluble $\mathrm{Cu}$ and $5.65 \%$ total $\mathrm{Fe}$. Ore acid consumption was $33.5 \mathrm{~kg} /$ ton ore as determined by a leaching aliquot and titration with $\mathrm{NaOH}$. The mineralogy was determined by quantitative X-ray diffraction (QXRD, Siemens/Bruker, Semi-QXRD, model D5000, Germany) and validated by optical microscopy using point-counting method (Table 1 ).

Table 1. Mineralogy of the ore determined by quantitative X-ray diffraction.

\begin{tabular}{cccc}
\hline Mineral & Chemical Formula & Amount (wt. \%) & Cu (wt. \%) \\
\hline Chalcopyrite & $\mathrm{CuFeS}_{2}$ & 1.69 & 0.59 \\
Bornite & $\mathrm{Cu}_{5} \mathrm{FeS}_{4}$ & 0.10 & 0.06 \\
Covellite & $\mathrm{CuS}$ & 0.02 & 0.01 \\
Atacamite & $\mathrm{CuCl}_{2} \cdot 3 \mathrm{Cu}(\mathrm{OH})_{2}$ & 0.07 & 0.04 \\
Chrysocolla & $\mathrm{Cu}_{1.75} \mathrm{Al}_{0.25} \mathrm{H}_{1.75}\left(\mathrm{Si}_{2} \mathrm{O}_{5}\right)(\mathrm{OH})_{4} \cdot 0.25\left(\mathrm{H}_{2} \mathrm{O}\right)$ & 0.01 & $<0.01$ \\
Pyrite & $\mathrm{FeS}_{2}$ & 3.81 & - \\
Magnetite & $\mathrm{Fe}_{3} \mathrm{O}_{4}$ & 0.40 & - \\
Hematite & $\mathrm{Fe}_{2} \mathrm{O}_{3}$ & 0.08 & - \\
Limonite & $\mathrm{FeOOH}^{2}$ & 0.07 & - \\
Quartz & $\mathrm{SiO}_{2}$ & 38.39 & 0.70 \\
Gangues & - & 55.36 & \\
\hline
\end{tabular}




\subsection{Reagents}

Technical grade sulfuric acid $\left(\mathrm{H}_{2} \mathrm{SO}_{4}, 95 \%\right)$, sodium chloride $(\mathrm{NaCl}, 95 \%)$, sodium nitrate $\left(\mathrm{NaNO}_{3}, 95 \%\right)$ and seawater were used as reactive agents. Seawater was obtained from San Jorge Bay, Antofagasta, Chile. It was pumped from the coast and then filtered (pore size $0.001 \mathrm{~mm}$ ) through a polyethylene membrane. The chemical analyses of seawater shown in Table 2 were obtained by volumetry, gravimetry, inductively coupled plasma atomic emission spectroscopy (ICP-AES, ICPE-9000, Shimadzu, Tokyo, Japan) and AAS.

Table 2. Seawater composition.

\begin{tabular}{|c|c|c|c|c|c|c|c|c|}
\hline \multirow{2}{*}{$\begin{array}{c}\begin{array}{c}\text { Method of } \\
\text { Analysis }\end{array} \\
\text { Ionic Species }\end{array}$} & \multicolumn{4}{|c|}{ ICP-AES } & \multicolumn{2}{|c|}{ AAS } & \multirow{2}{*}{$\begin{array}{c}\begin{array}{c}\text { Volumetric } \\
\text { Analysis }\end{array} \\
\mathrm{Cl}^{-}\end{array}$} & \multirow{2}{*}{$\begin{array}{c}\begin{array}{c}\text { Gravimetric } \\
\text { Analysis }\end{array} \\
\mathrm{SO}_{4}{ }^{2-}\end{array}$} \\
\hline & $\mathrm{Na}^{+}$ & $\mathrm{Mg}^{2+}$ & $\mathrm{Ca}^{2+}$ & $\mathrm{K}^{+}$ & $\mathrm{Cu}^{2+}$ & $\mathrm{NO}_{3}{ }^{-}$ & & \\
\hline Amount $(\mathrm{g} / \mathrm{L})$ & 10.73 & 1.29 & 0.40 & 0.39 & $7.2 \times 10^{-5}$ & $3 \times 10^{-3}$ & 20.06 & 2.81 \\
\hline
\end{tabular}

\subsection{Experimental Procedure}

\subsubsection{Description of Pretreatment Stage}

Table 3 shows the variables used to study the effect of pretreatment on copper extraction

Table 3. Variables studied in the pretreatment step.

\begin{tabular}{cccc}
\hline $\begin{array}{c}\text { Sodium Nitrate } \\
\text { Addition (kg/ton) }\end{array}$ & $\begin{array}{c}\text { Sodium Chloride } \\
\text { Addition (kg/ton) }\end{array}$ & Curing Time (Days) & Repose Temperature $\left({ }^{\circ} \mathrm{C}\right)$ \\
\hline 11.7 & $2.1^{*}$ & 20 & 25 \\
23.3 & 19.8 & 30 & 45 \\
\hline
\end{tabular}

Ten copper sulfide ore samples were prepared (500 g), all with the same granulometry. The ore was placed on a plastic sheet where the sodium nitrate and sodium chloride were added, both in solid form. The ore and reactive agents were homogenized by rolling, after which $50 \%$ of the sulfuric acid consumption of the ore $(16.8 \mathrm{~kg} / \mathrm{ton})$ was added and $7 \%$ moisture was obtained by adding seawater. The ore was homogenized and the formation of stable agglomerates was observed. The agglomerated ore was stored in sealed plastic bags, the weight of which was registered using an analytical balance (Mettler Toledo C. AX-204, precision of $\pm 7 \times 10^{-5} \mathrm{~g}$ ). To test the effect of a repose temperature of $45^{\circ} \mathrm{C}$, pretreated samples were placed in an oven (Binder model ED115) that remained constant at that temperature throughout the repose period. To test the effect of a repose temperature of $25^{\circ} \mathrm{C}$, the samples were left in the laboratory with temperature control set at that temperature. The moisture level in the samples was checked every two days. Variation in weight indicated moisture loss by evaporation, the samples were sprayed with distilled water until the original weight was obtained. Following the repose period, the pretreated ore was transferred to a beaker, washed with distilled water at a solid/liquid ratio of 1:3 at room temperature, with mechanical agitation (400 rpm) for two hours. The suspension was then filtered using a vacuum pump. The $\mathrm{pH}$ and redox potential (ORP) of the resulting solution were then measured (Hanna portable pH/ORP meter, model HI991003, accuracy $\pm 0.02 \mathrm{pH}$ and $\pm 2 \mathrm{mV}$ ). The solid residue was dried in an oven at $60^{\circ} \mathrm{C}$ until reaching a constant weight. The copper content in the solution and in the solid residue was obtained by AAS. The copper extraction rate was calculated using the copper grades of the head and residual ore, which was corroborated with the results obtained by solutions. A standard deviation of $\pm 2 \%$ was obtained by calculating the copper extraction rates from solid and solution for all the tests. These tests were carried out in duplicate. 


\subsubsection{Description of Leaching Tests}

The pretreatment conditions that resulted in the highest copper extraction rate were repeated in three experiments using $3 \mathrm{~kg}$ of ore with the same size distribution as in the previous tests. The pretreated ore was placed in acrylic mini-columns $40 \mathrm{~cm}$ high and $9.5 \mathrm{~cm}$ in diameter, similar dimensions used by Taboada et al. [50] and Velasquez-Yévenez et al. [51], and left in repose for a curing time determined by the previous tests. Following the curing time, the ore was leached using a solution of $6.3 \mathrm{~g} / \mathrm{L} \mathrm{NaNO}_{3}$ and seawater, with a $\mathrm{pH}$ of 1 (using $\mathrm{H}_{2} \mathrm{SO}_{4}$ ), and the experimental variables as shown in Table 4. The mini columns at $45^{\circ} \mathrm{C}$ were wrapped in plastic hoses through which water circulated at a desired temperature, controlled by a thermostatic bath (Julabo bath F25-ME Refrigerated/Heating Circulator) to keep the temperature constant (Figure 1).

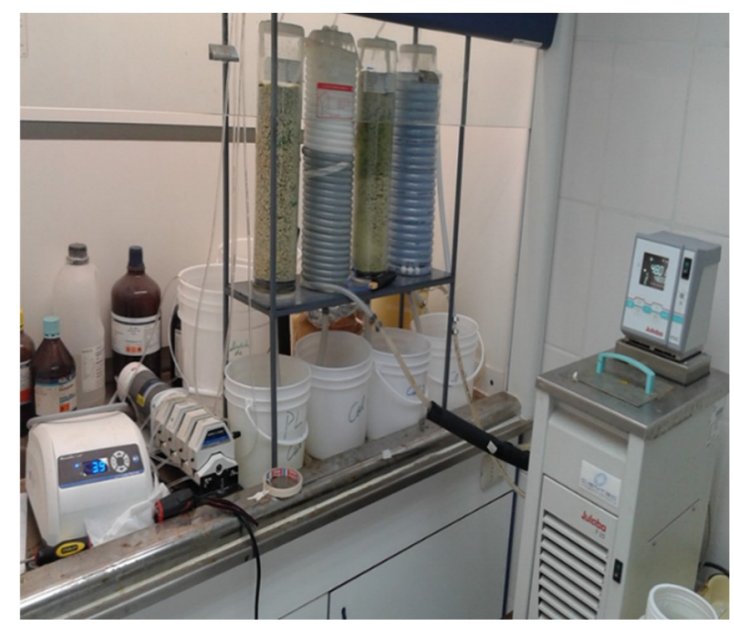

Figure 1. Mini-column leaching tests.

Table 4. Experimental conditions of mini-column leaching tests.

\begin{tabular}{cccc}
\hline Conditions & C1 & C2 & C3 \\
\hline Irrigation temperature $\left({ }^{\circ} \mathrm{C}\right)$ & 25 & 45 & 25 \\
Chloride $(\mathrm{g} / \mathrm{L})$ & 20 & 20 & 40 \\
\hline
\end{tabular}

The mini-columns were irrigated with a peristaltic pump in an open cycle at a rate of $8 \mathrm{~L} / \mathrm{h} \cdot \mathrm{m}^{2}$ (Master Flex, Model $N^{\circ}$ 7557-14/1-100 RPM, Cole-Parmer International, Vernon Hills, IL, USA). At certain intervals, the output solution was removed and mass, $\mathrm{pH}$, ORP and copper content were determined. Following the test (leaching for 8 days), the ore was washed in the mini-columns with an acid solution ( $\mathrm{pH} 1$ ) and tap water for $24 \mathrm{~h}$ and then left in repose for another $24 \mathrm{~h}$ to completely drain the solution. The leached ore was then removed from the mini-columns and dried in an oven at $60{ }^{\circ} \mathrm{C}$ until reaching a constant weight. The solid residue was analyzed for copper content (AAS). A standard deviation of $\pm 1.9 \%$ was obtained by calculating copper extraction using solid and solution for all the tests. The tests were carried out in duplicate. In addition, the solid residue was analyzed by optical microscope for the determination of mineralogical species.

\section{Results and Discussion}

\subsection{Effect of Pretreatment on Copper Extraction}

Table 5 shows the pretreatment tests, with all the variables used and the average of copper extraction.

The highest copper extraction was obtained in test 8 , which involved the highest values of the studied variables. The final $\mathrm{pH}$ levels in all the tests were in the range of 2.2 to 3.3 , which indicates 
complete consumption of the aggregate acid in the pretreatment. Redox potential values ranged between 637 and $792 \mathrm{mV}$ (vs SHE), which were higher than the values reported by Cerda et al. [48]. This is attributed to the presence of nitrate, which has a high redox potential. Temperature and the addition of chloride have significant effects on dissolving copper sulfides. The residue obtained from test 8 was analyzed by optical microscope. Figure 2 shows the percentages of the copper species extracted in test 8 by leaching with pretreatment, which was determined by mass balance.

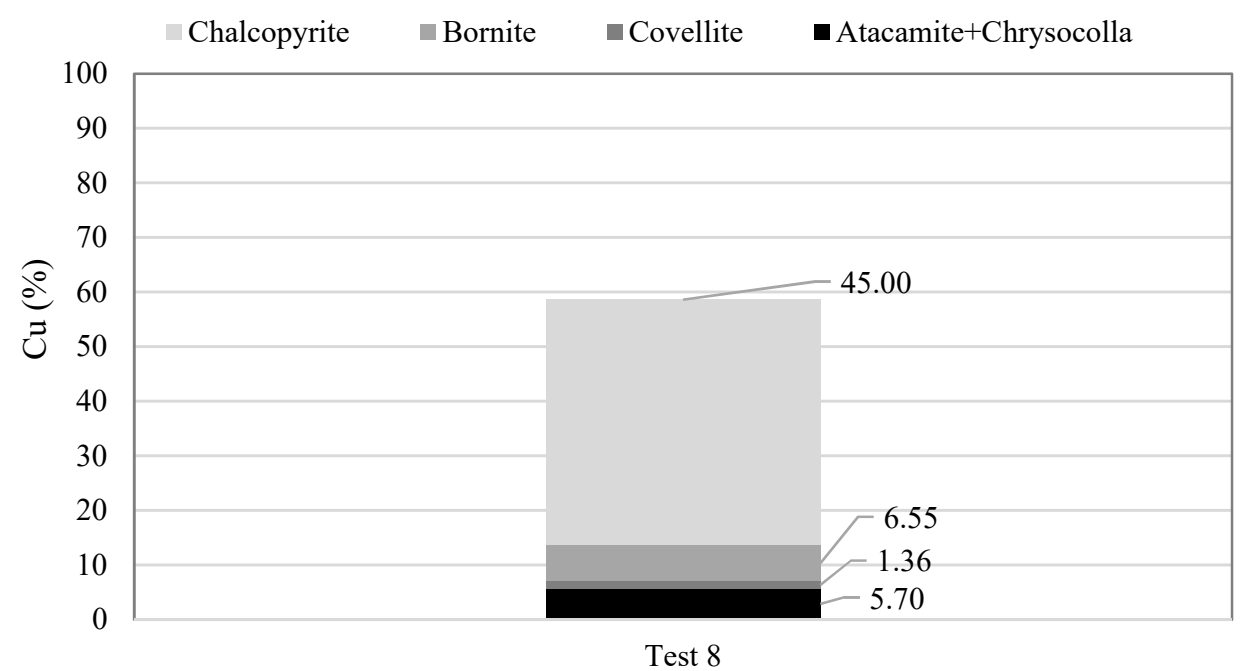

Figure 2. Copper extraction by sequential leaching mineralogical copper species obtained in test 8 . Experimental conditions: $23.3 \mathrm{~kg} \mathrm{NaNO} /$ ton, $19.8 \mathrm{~kg} \mathrm{NaCl} /$ ton, 30 days of repose at $45^{\circ} \mathrm{C}$.

Table 5. Pretreatment tests and maximum copper extraction (wt. \%).

\begin{tabular}{cccccc}
\hline Test & $\begin{array}{c}\text { Sodium Nitrate } \\
\text { Addition (kg/ton) }\end{array}$ & $\begin{array}{c}\text { Sodium Chloride } \\
\text { Addition (kg/ton) }\end{array}$ & $\begin{array}{c}\text { Curing Time } \\
\text { (Days) }\end{array}$ & $\begin{array}{c}\text { Temperature } \\
\left({ }^{\circ} \mathbf{C}\right)\end{array}$ & $\begin{array}{c}\text { Cu Extraction } \\
\text { (wt. } \%)\end{array}$ \\
\hline 1 & 11.7 & 2.1 & 20 & 45 & 19.8 \\
2 & 23.3 & 2.1 & 20 & 45 & 22.9 \\
3 & 11.7 & 19.8 & 20 & 45 & 34.9 \\
4 & 23.3 & 19.8 & 20 & 45 & 36.6 \\
5 & 11.7 & 2.1 & 30 & 45 & 28.7 \\
6 & 23.3 & 2.1 & 30 & 45 & 30.7 \\
7 & 11.7 & 19.8 & 30 & 45 & 44.9 \\
8 & 23.3 & 19.8 & 30 & 45 & 58.6 \\
9 & 11.7 & 2.1 & 30 & 25 & 11.8 \\
10 & 23.3 & 2.1 & 30 & 25 & 22.8 \\
\hline
\end{tabular}

Table 6 shows the copper extraction per mineralogical species and the percentages of the minerals present at the beginning and end of the pretreatment stage.

According to the results shown in Table 6, part of bornite (75\%), covellite $(95 \%)$ and chalcopyrite $(53.3 \%)$ were only leached with the pretreatment stage. Copper oxide minerals were completely leached.

Table 6. Copper extraction (\%) per mineralogical species and presence (\%) in the feed ore and solid residue of pretreatment (test 8 ).

\begin{tabular}{cccc}
\hline Mineral & Extraction (\%) & Feed Ore (\%) & Pretreatment Ore (\%) \\
\hline Chalcopyrite & 53.3 & 1.69 & 0.79 \\
Bornite & 75.0 & 0.10 & 0.03 \\
Covellite & 95.0 & 0.02 & $<0.01$ \\
Atacamite & 100.0 & 0.07 & 0 \\
Chrysocolla & 100.0 & 0.01 & 0 \\
\hline
\end{tabular}




\subsubsection{Effect of Adding Chloride}

The addition of chloride increased copper extraction in all the tests, which concurs with what was reported by Senanayake [52] and Watling [6], where chalcopyrite and bornite oxidized more readily in saline water media. The highest extraction of $58.6 \%$ was obtained in the test with the addition of $23.3 \mathrm{~kg}$ of sodium nitrate and $19.8 \mathrm{~kg}$ of sodium chloride per ton at $45^{\circ} \mathrm{C}$, with 30 days of repose. According to Velásquez-Yévenes and Quezada-Reyes [21], the pretreatment with acid and chloride resulted in a more homogenous distribution of reactive agents in the ore, resulting in the dissolution reaction beginning earlier and the formation of soluble species, with better liquid/solid interaction and a higher degree of porosity in the bed, so that moisture is retained in the pores. Velásquez-Yévenes [51] determined that adding sodium chloride in a curing stage improves copper extraction from copper sulfate, based on a test comparing extraction with and without the addition of chloride. They demonstrated that increasing the quantity of chloride from 20 to $70 \mathrm{~kg} /$ ton does not significantly increase the copper extraction. This finding concurs with the results of other authors $[15,16]$.

\subsubsection{Effect of Adding Nitrate}

The addition of sodium nitrate had a positive effect in all the tests, particularly in the test with 30 days of repose at $45^{\circ} \mathrm{C}$ and the addition of a high level of chloride. The additional nitrate resulted in more oxidizing ions being available to leach copper sulfides. This concurs with what was reported by Sokić et al. [27], who confirmed that a system with sulfuric acid without the addition of oxidants does not react with chalcopyrite. A mixture with high concentrations of sodium chloride and sodium nitrate in an acid medium was more effective, which concurs with Shiers et al. [33], who reported a $92 \%$ extraction for the $\mathrm{NO}_{3}{ }^{-} / \mathrm{FeCl}_{3}\left(50^{\circ} \mathrm{C}, 168 \mathrm{~h}\right)$ oxidant. The authors suggested that nitrate is the most cost-effective oxidant.

\subsubsection{Effect of Curing Time}

Increasing the curing time from 20 to 30 days increased copper extraction in all the tests by providing more time for the dissolution reaction to occur. This is because the mineral is exposed to a high ionic charge provided by sodium nitrate, sodium chloride and sulfuric acid, which, along with a low amount of water, allow dissolution reactions to occur rapidly. This concurs with Cerda et al. [48], Velásquez-Yévenes and Quezada-Reyes [21], and Velásquez-Yévenes et al. [51] who found that a higher extraction was obtained with a longer repose period.

\subsubsection{Effect of Repose Temperature}

Dissolution reactions are more rapid with higher temperatures because less energy is necessary to activate dissolution and to break molecular bonds and thus dissolve mineralogical species in contact with the leaching agents [48].

\subsubsection{Chemical Reactions in Pretreatment}

Table 7 shows the main proposed reactions that can occur during agglomeration and curing.

Table 7. Chemical reactions proposed for the pretreatment stage in acid-chloride-nitrate media.

\begin{tabular}{|c|c|c|}
\hline Mineral & Proposed Chemical Reaction & $\mathbf{N}^{\circ}$ \\
\hline $\mathrm{CuFeS}_{2}$ & $\begin{array}{c}2 \mathrm{CuFeS} 2+10 \mathrm{H}_{2} \mathrm{SO}_{4}+10 \mathrm{NaNO}_{3}+4 \mathrm{NaCl} \rightarrow \\
2 \mathrm{CuCl}_{2}+\mathrm{Fe}_{2}\left(\mathrm{SO}_{4}\right)_{3}+10 \mathrm{NO}_{2}+4 \mathrm{~S}+10 \mathrm{H}_{2} \mathrm{O}+7 \mathrm{Na}_{2} \mathrm{SO}_{4}\end{array}$ & (3) \\
\hline $\mathrm{CuS}$ & $\begin{array}{l}3 \mathrm{CuS}+4 \mathrm{H}_{2} \mathrm{SO}_{4}+2 \mathrm{NaNO}_{3}+6 \mathrm{NaCl} \rightarrow \\
3 \mathrm{CuCl}_{2}+2 \mathrm{NO}+3 \mathrm{~S}+4 \mathrm{H}_{2} \mathrm{O}+4 \mathrm{Na}_{2} \mathrm{SO}_{4}\end{array}$ & (4) \\
\hline $\mathrm{Cu}_{5} \mathrm{FeS}_{4}$ & $\begin{array}{c}\mathrm{Cu}_{5} \mathrm{FeS}_{4}+12 \mathrm{H}_{2} \mathrm{SO}_{4}+12 \mathrm{NaNO}_{3}+10 \mathrm{NaCl} \rightarrow \\
5 \mathrm{CuCl}_{2}+\mathrm{FeSO}_{4}+12 \mathrm{NO}_{2}+4 \mathrm{~S}+12 \mathrm{H}_{2} \mathrm{O}+11 \mathrm{Na}_{2} \mathrm{SO}_{4}\end{array}$ & (5) \\
\hline $\mathrm{FeS}_{2}$ & $\begin{array}{l}3 \mathrm{FeS}_{2}+4 \mathrm{H}_{2} \mathrm{SO}_{4}+2 \mathrm{NaNO}_{3}+6 \mathrm{NaCl} \rightarrow \\
3 \mathrm{FeCl}_{2}+2 \mathrm{NO}+6 \mathrm{~S}+4 \mathrm{H}_{2} \mathrm{O}+4 \mathrm{Na}_{2} \mathrm{SO}_{4}\end{array}$ & (6) \\
\hline
\end{tabular}


Table 8 shows the standard Gibbs energy of proposed reactions 3 to 6 at temperatures of 25 and $45^{\circ} \mathrm{C}$, which were calculated with HSC software [53].

Table 8. Standard Gibbs energy values at 25 and $45{ }^{\circ} \mathrm{C}$ of proposed chemical reactions for the pretreatment stage.

\begin{tabular}{ccc}
\hline Equation $\mathbf{N}^{\circ}$ & $\boldsymbol{\Delta G}^{\circ}{ }_{\mathbf{2 5}}{ }^{\circ} \mathbf{C}(\mathbf{k c a l} / \mathbf{m o l})$ & $\boldsymbol{\Delta G}^{\circ}{ }_{\mathbf{4 5}}{ }^{\circ} \mathbf{C}(\mathbf{k c a l} / \mathbf{m o l})$ \\
\hline 3 & -209.5 & -216.8 \\
4 & -97.8 & -98.8 \\
5 & -234.4 & -243.0 \\
6 & -115.5 & -117.4 \\
\hline
\end{tabular}

As can be observed, all the reactions are thermodynamically feasible at atmospheric pressure and in a temperature range of 25 to $45^{\circ} \mathrm{C}$.

\subsection{Effect on Mini-Column Leaching}

Test C1 obtained a copper extraction of $63.9 \%$, while test C2 obtained one of $55.0 \%$, and test C3 one of $55.4 \%$. Figure 3 shows the copper extraction curves versus the repose period and subsequent leaching for columns 1 to 3 . Table 4 shows the leaching conditions.

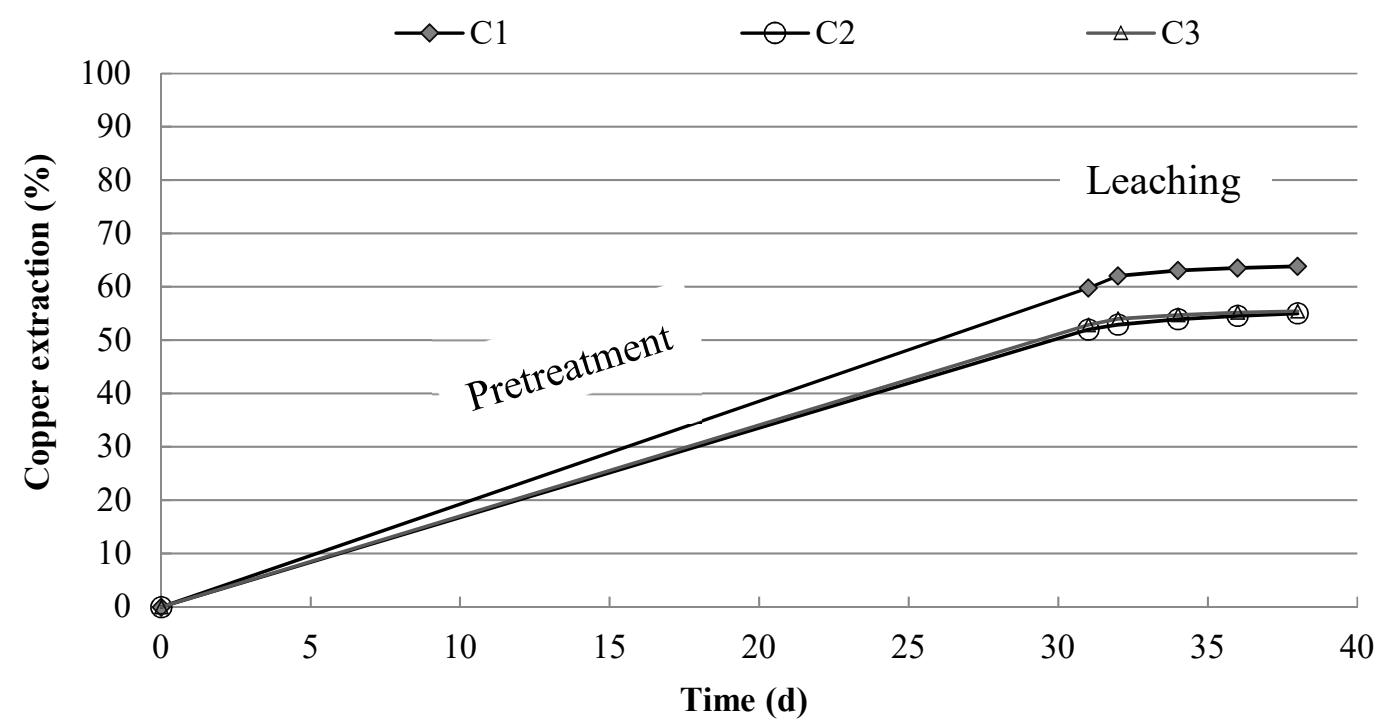

Figure 3. Copper extraction rate (\%) vs. time (d) in mini-columns, leaching pretreated ore with $16.8 \mathrm{~kg}$ sulfuric acid/ton, $23.3 \mathrm{~kg}$ sodium nitrate/ton, $19.8 \mathrm{~kg}$ sodium chloride/ton, 30 days of curing time at $45^{\circ} \mathrm{C}$. Irrigation conditions: $\mathrm{pH} 1,6.3 \mathrm{~g}$ sodium nitrate/L, seawater. $\mathrm{C} 1: 25^{\circ} \mathrm{C}$ and $20 \mathrm{~g}$ chloride/L, $\mathrm{C} 2$ : $45^{\circ} \mathrm{C}$ and $20 \mathrm{~g}$ chloride/L, and $\mathrm{C} 3: 25^{\circ} \mathrm{C}$ and $40 \mathrm{~g}$ chloride/L.

It can be seen from Figure 3 that the highest copper extraction of $63.9 \%$ was obtained with $\mathrm{C} 1$ at $38 \mathrm{~d}$ (30 d of pretreatment and $8 \mathrm{~d}$ of leaching) at $25^{\circ} \mathrm{C}$. The pretreatment resulted in high dissolution rates in all the experiments. Velásquez-Yévenes and Quezada-Reyes [21] conducted chalcopyrite leaching tests in columns at room temperature, with 30 days of repose and 55-60 days of irrigation with sulfuric acid, cupric ions and seawater or brine. The highest copper extraction obtained was less than $25 \%$. Comparing this to the results with $\mathrm{C} 1$, it is evident that nitrate is the most favorable oxidizing agent for extracting copper. Figure 3 shows that the $\mathrm{C} 2$ and $\mathrm{C} 3$ curves have similar kinetics. The two columns show differences in temperature and chloride concentrations. According to the results, temperature can be replaced by chloride concentration. This concurs with what was found in the pretreatment stage, where the two variables are the most significant in the dissolution system. 
$\mathrm{C} 1$ reached a copper extraction of $63.9 \%$ with 8 days of leaching. Comparing this result to the extraction obtained in the pretreatment stage alone (58.6\%), it can be observed that the leaching stage is only improved by $9 \%$. C 2 and C 3 obtained copper extraction close to that obtained in the pretreatment, from which it can be inferred that the leaching only washed the solubilized species during the pretreatment. No contribution from the leaching process was observed.

Based on our results, pretreatment is recommended, followed by washing with an acid solution $(\mathrm{pH} 1)$ in the leaching process, without other additives like nitrate or chloride. Other options include using higher concentrations of nitrate (greater oxidation potential), other oxidants, or higher concentrations of acid, among others. The process could also be carried out in two stages, first an acid wash of the pretreated ore, followed by oxidative leaching.

The $\mathrm{pH}$ levels of the output solutions of the three columns were $\geq 1.5$, indicating acid consumption. The patterns of redox potential values (Figure 4) were similar for $\mathrm{C} 1$ and $\mathrm{C} 3$, and higher than those obtained for $\mathrm{C} 2$. The redox potential values of $\mathrm{C} 2$ indicate that there are fewer oxidants in the system at $45^{\circ} \mathrm{C}$ than at $25^{\circ} \mathrm{C}$.

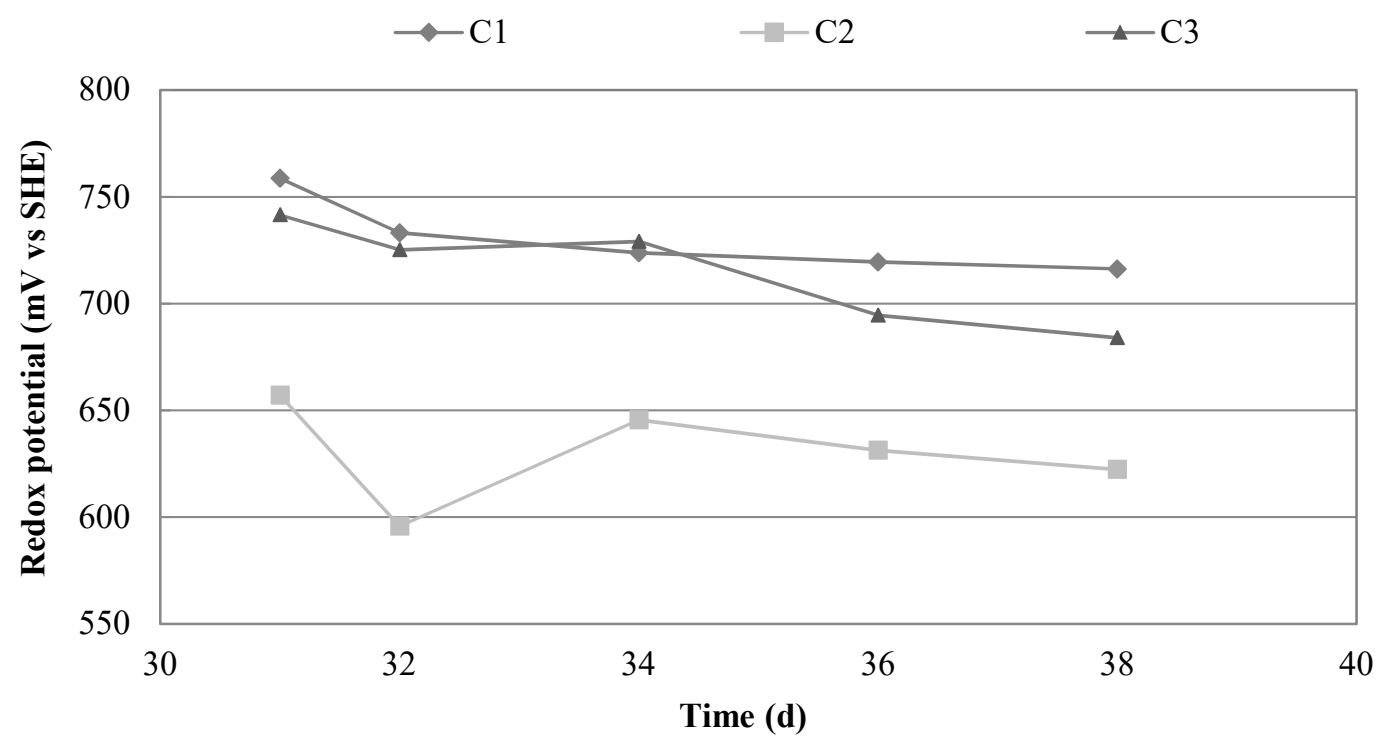

Figure 4. Redox potential (mV vs. SHE) vs. time (d) in mini-columns leaching of pretreated ore with $16.8 \mathrm{~kg}$ sulfuric acid/ton, $23.3 \mathrm{~kg}$ sodium nitrate/ton, $19.8 \mathrm{~kg}$ sodium chloride/ton, 30 days of curing at $45^{\circ} \mathrm{C}$. Irrigation conditions: $\mathrm{pH} 1,6.3 \mathrm{~g}$ sodium nitrate/L, seawater. $\mathrm{C} 1: 25^{\circ} \mathrm{C}$ and $20 \mathrm{~g}$ chloride/L, $\mathrm{C} 2$ : $45^{\circ} \mathrm{C}$ and $20 \mathrm{~g}$ chloride/L, and C $3: 25^{\circ} \mathrm{C}$ and $40 \mathrm{~g}$ chloride/L.

\subsubsection{Effect of Temperature on the Leaching Stage}

The copper extraction was lower at $45^{\circ} \mathrm{C}$ than at $25^{\circ} \mathrm{C}$, which could be because the mini-columns are open to the air, so that $\mathrm{NOx}$ gas formed by the reaction between $\mathrm{H}_{2} \mathrm{SO}_{4}$ and $\mathrm{NaNO}_{3}$ escape from the leaching system, which results at $45^{\circ} \mathrm{C}$ in fewer nitrate ions being available for the copper dissolution reaction, as shown in Equation (7):

$$
2 \mathrm{NaNO}_{3}+\mathrm{H}_{2} \mathrm{SO}_{4} \rightarrow 2 \mathrm{HNO}_{3(\mathrm{~g})}+\mathrm{Na}_{2} \mathrm{SO}_{4}
$$

With $\Delta \mathrm{G}_{25}{ }^{\circ} \mathrm{C}=1.3 \mathrm{kcal} / \mathrm{mol}$ and $\Delta \mathrm{G}_{45}{ }^{\circ} \mathrm{C}=-0.1 \mathrm{kcal} / \mathrm{mol}$.

Oxidant loss could not occur at $25^{\circ} \mathrm{C}$, therefore the availability of oxidants would be higher than at $45^{\circ} \mathrm{C}$ which would affect the copper dissolution.

The redox potential values in the output solutions of $\mathrm{C} 1$ and $\mathrm{C} 3$ were higher than that of $\mathrm{C} 2$ (see Figure 4), which could be due to a smaller quantity of oxidant in the $\mathrm{C} 2$ medium than in those of $\mathrm{C} 1$ or C3. It could also be due to ferric sulfate being generated in C2 by the pretreatment, which would 
have reacted with chalcopyrite in the leaching stage, forming ferrous sulfate and resulting in a lower redox potential.

$$
\begin{gathered}
\mathrm{CuFeS}_{2}+4 \mathrm{Fe}^{3+} \rightarrow \mathrm{Cu}^{2+}+5 \mathrm{Fe}^{2+}+2 \mathrm{~S} \\
\mathrm{CuFeS}_{2}+4 \mathrm{Fe}^{3+}+\mathrm{Cl}^{-} \rightarrow \mathrm{CuCl}^{+}+5 \mathrm{Fe}^{2+}+2 \mathrm{~S}
\end{gathered}
$$

With $\Delta \mathrm{G}_{25}{ }^{\circ} \mathrm{C}=-31.9 \mathrm{kcal} / \mathrm{mol}$ equation 8 and $\Delta \mathrm{G}_{25}{ }^{\circ} \mathrm{C}=-32.4 \mathrm{kcal} / \mathrm{mol}$ Equation (9).

The results obtained indicate that under the conditions used in this study, copper dissolution is not favored by increasing the temperature from 25 to $45^{\circ} \mathrm{C}$.

\subsubsection{Effect of Chloride Concentration on Leaching Stage}

Copper extraction rates was higher in the column with $20 \mathrm{~g} / \mathrm{L}$ of chloride (C1) than in the column with $40 \mathrm{~g} / \mathrm{L}$ (C3), which could be due to greater saturation of the leaching medium (more ionic strength) in a higher chloride concentration, which is unfavorable for copper dissolution under the studied conditions. Several authors have determined that the presence of chloride ions in leaching systems improves copper extraction $[6,8,9]$. However, the increase in chloride concentration is not necessarily proportional to the copper extraction rate $[15,51]$.

\subsubsection{Analyses of Solid Residues}

Table 9 shows the residual mineral species in $\mathrm{C} 1$ obtained by leaching test (observed with an optical microscope) in comparison to the original mineralogical state (head ore).

Table 9. Mineralogy of initial ore and solid residue of C1.

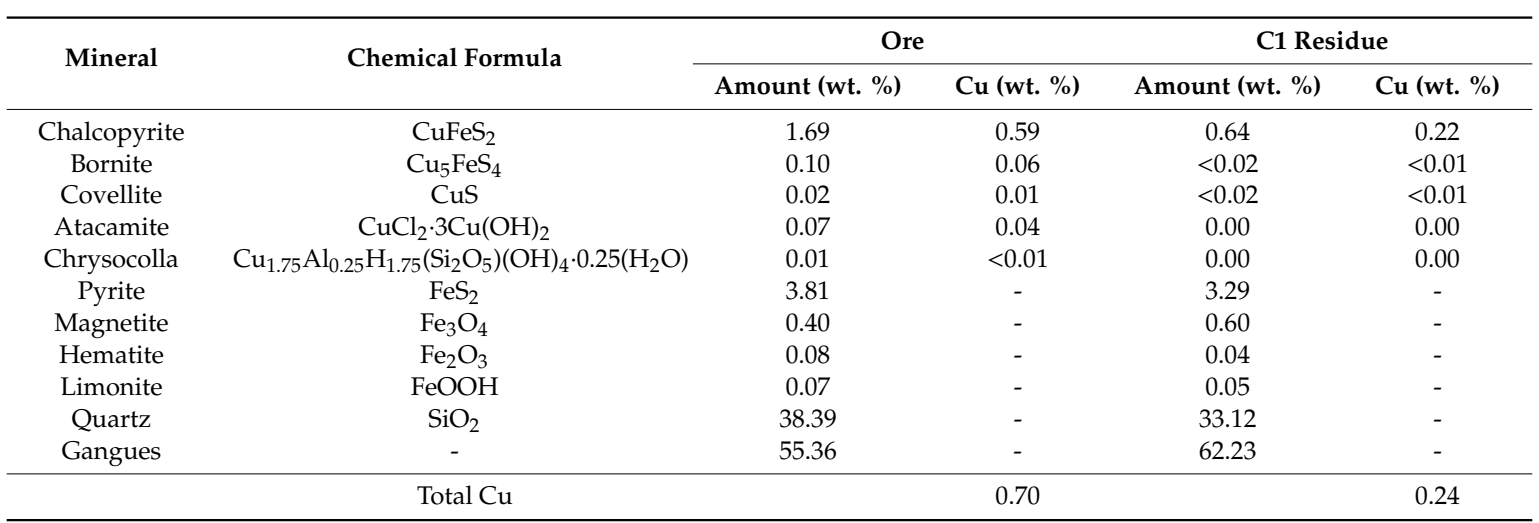

Table 9 shows the presence of copper sulfide in the residue, with reduced levels of chalcopyrite, bornite and covellite, while copper oxide was totally leached. It is possible to dissolve $62 \%$ of the chalcopyrite in the ore using a pretreatment/leaching process in acid-nitrate-chloride media.

\section{Conclusions}

We studied the effects of a pretreatment stage, adding nitrate and chloride and varying repose time and temperature on chalcopyrite dissolution in acid-nitrate-chloride media. The main findings are:

- The copper sulfide pretreatment provided satisfactory results, with $58.6 \% \mathrm{Cu}$ extraction with the addition of $23.3 \mathrm{~kg}$ sodium nitrate and $19.8 \mathrm{~kg}$ sodium chloride per ton, and 30 days of curing time at $45^{\circ} \mathrm{C}$.

- The acid-nitrate-chloride media at high concentrations was effective in the pretreatment, providing oxidizing ions in the repose period. 
- A copper extraction of $63 \%$ was obtained by leaching pretreated ore in mini-columns using a leaching solution of $6.3 \mathrm{~g} / \mathrm{L}$ of sodium nitrate and $20 \mathrm{~g} / \mathrm{L}$ of chloride at $\mathrm{pH} 1$ and a temperature of $25{ }^{\circ} \mathrm{C}$. Raising the temperature and increasing the chloride concentration did not improve copper extraction rates under the studied conditions.

- Chalcopyrite, bornite and covellite were only partially leached in the mini-columns, while copper oxides were completely leached.

- A favorable copper dissolution from sulfide ore was obtained in acid-nitrate-chloride media with the inclusion of a pretreatment stage in the leaching system. Waste salts from the caliche industry can be used for the nitrate medium, while waste brine from reverse osmosis can provide the chloride medium.

- An emphasis on the pretreatment stage is proposed given that this results in copper extraction rates in the range of $60 \%$, so in the next phase only an acid wash will be required.

Author Contributions: Conceptualization, P.C.H. and Y.P.J.; Formal analysis, O.O.H. and C.M.T.; Investigation, J.D.; Supervision, P.C.H. and Y.P.J.; Validation, O.O.H. and C.M.T.; Writing-original draft, P.C.H.

Funding: The authors are grateful for the financial support provided by CONICYT through Fondecyt Iniciación Project N ${ }^{\circ} 11170179$ and PAI/Concurso Nacional Inserción en la Academia, Convocatoria 2015 folio Nº 79150003.

Acknowledgments: Special thanks to Departamento de Ingeniería en Minas and Laboratorio de Investigación de procesos of Departamento de Ingeniería Química y Procesos de Minerales, of Universidad de Antofagasta for the assistance in ore preparation and technical support with equipment and materials.

Conflicts of Interest: The authors declare no conflict of interest.

\section{References}

1. Baba, A.A.; Ayinla, K.I.; Adekola, F.A.; Ghosh, M.K.; Ayanda, O.S.; Bale, R.B.; Sheik, A.R.; Pradhan, S.R. A review on novel techniques for chalcopyrite ore processing. Int. J. Min. Eng. Miner. Process. 2012, 1, 1-16. [CrossRef]

2. Watling, H. Chalcopyrite hydrometallurgy at atmospheric pressure: 1. Review of acidic sulfate, sulfate-chloride and sulfate-nitrate process options. Hydrometallurgy 2013, 140, 163-180. [CrossRef]

3. Wang, S. Copper leaching from chalcopyrite concentrates. JOM J. Miner. Met. Mater. Soc. 2005, 57, 48-51. [CrossRef]

4. Barriga, F.; Palencia, I.; Carranza, F. The passivation of chalcopyrite subjected to ferric sulfate leaching and its reactivation with metal sulfides. Hydrometallurgy. 1987, 19, 159-167. [CrossRef]

5. Klauber, C. A critical review of the surface chemistry of acidic ferric sulphate dissolution of chalcopyrite with regards to hindered dissolution. Int. J. Miner. Process. 2008, 86, 1-17. [CrossRef]

6. Watling, H. Chalcopyrite hydrometallurgy at atmospheric pressure: 2. Review of acidic chloride process options. Hydrometallurgy 2014, 146, 96-110. [CrossRef]

7. Ruiz, M.; Montes, K.; Padilla, R. Chalcopyrite leaching in sulfate-chloride media at ambient pressure. Hydrometallurgy 2011, 109, 37-42. [CrossRef]

8. Velásquez-Yévenes, L.; Nicol, M.; Miki, H. The dissolution of chalcopyrite in chloride solutions: Part 1: The effect of solution potential. Hydrometallurgy 2010, 103, 108-113. [CrossRef]

9. Velásquez, L.; Miki, H.; Nicol, M. The dissolution of chalcopyrite in chloride solutions: Part 2: Effect of various parameters on the rate. Hydrometallurgy 2010, 103, 80-85.

10. Veloso, T.C.; Peixoto, J.J.; Pereira, M.S.; Leao, V.A. Kinetics of chalcopyrite leaching in either ferric sulphate or cupric sulphate media in the presence of $\mathrm{NaCl}$. Int. J. Miner. Process. 2016, 148, 147-154. [CrossRef]

11. Dutrizac, J. The leaching of sulphide minerals in chloride media. Hydrometallurgy 1992, 29, 1-45. [CrossRef]

12. Nicol, M.; Miki, H.; Velásquez-Yévenes, L. The dissolution of chalcopyrite in chloride solutions: Part 3. Mechanisms. Hydrometallurgy 2010, 103, 86-95. [CrossRef]

13. Herreros, O.; Quiroz, R.; Restovic, A.; Viñals, J. Dissolution kinetics of metallic copper with $\mathrm{CuSO}_{4}-\mathrm{NaCl}-\mathrm{HCl}$. Hydrometallurgy 2005, 77, 183-190.

14. Jamett, N.E.; Hernández, P.C.; Casas, J.M.; Taboada, M.E. Speciation in the Fe (III)-Cl (I)-H ${ }_{2} \mathrm{O}$ System at 298.15 K, $313.15 \mathrm{~K}$, and $333.15 \mathrm{~K}\left(25^{\circ} \mathrm{C}, 40^{\circ} \mathrm{C}\right.$ and $\left.60^{\circ} \mathrm{C}\right)$. Metall. Mater. Trans. B. 2017, 49, 1-9. [CrossRef] 
15. Carneiro, M.F.C.; Leão, V.A. The role of sodium chloride on surface properties of chalcopyrite leached with ferric sulphate. Hydrometallurgy 2007, 87, 73-82. [CrossRef]

16. Lu, Z.Y.; Jeffrey, M.I.; Lawson, F. The effect of chloride ions on the dissolution of chalcopyrite in acidic solutions. Hydrometallurgy 2000, 56, 189-202. [CrossRef]

17. Hernández, P.; Taboada, M.; Herreros, O.; Torres, C.; Ghorbani, Y. Chalcopyrite dissolution using seawater-based acidic media in the presence of oxidants. Hydrometallurgy 2015, 157, 325-332. [CrossRef]

18. Watling, H.; Shiers, D.; Li, J.; Chapman, N.; Douglas, G. Effect of water quality on the leaching of a low-grade copper sulfide ore. Miner. Eng. 2014, 58,39-51. [CrossRef]

19. Torres, C.; Taboada, M.; Graber, T.; Herreros, O.; Ghorbani, Y.; Watling, H. The effect of seawater based media on copper dissolution from low-grade copper ore. Miner. Eng. 2015, 71, 139-145. [CrossRef]

20. Cisternas, L.; Moreno, L. El Agua De Mar En La Minería: Fundamentos Y Aplicaciones; Ril editors: Santiago, Chile, 2014.

21. Velásquez-Yévenes, L.; Quezada-Reyes, V. Influence of seawater and discard brine on the dissolution of copper ore and copper concentrate. Hydrometallurgy 2018, 180, 88-95. [CrossRef]

22. Cisternas, L.A.; Gálvez, E.D. The use of seawater in mining. Miner. Process. Extr. Metall. Rev. 2018, 39, 18-33. [CrossRef]

23. Padilla, R.; Vega, D.; Ruiz, M.C. Pressure leaching of sulfidized chalcopyrite in sulfuric acid-oxygen media. Hydrometallurgy 2007, 86, 80-88. [CrossRef]

24. Herreros, O.; Quiroz, R.; Campos, I.; Rojas, J.; Viñals, J. Lixiviación de concentrados calcopiriticos con cloro. Innovación 2001, 13, 7-15.

25. Córdoba, E.M.; Muñoz, J.A.; Blázquez, M.L.; González, F.; Ballester, A. Leaching of chalcopyrite with ferric ion. Part I: General aspects. Hydrometallurgy 2008, 93, 81-87. [CrossRef]

26. Lu, J.; Dreisinger, D. Copper leaching from chalcopyrite concentrate in $\mathrm{Cu}$ (II)/Fe (III) chloride system. Miner. Eng. 2013, 45, 185-190. [CrossRef]

27. Sokić, M.D.; Marković, B.; Živković, D. Kinetics of chalcopyrite leaching by sodium nitrate in sulphuric acid. Hydrometallurgy 2009, 95, 273-279. [CrossRef]

28. Habashi, F. Nitric acid in the hydrometallurgy of sulfides. In EPD Congress; The Minerals, Metals \& Materials Society: McCandless, PA, USA, 1999.

29. Habashi, F. Action of nitric acid on chalcopyrite. Trans. Soc. Min. Eng Aime. Aime. 1973, 254, $224-228$.

30. Gok, O.; Anderson, C.G. Dissolution of low-grade chalcopyrite concentrate in acidified nitrite electrolyte. Hydrometallurgy 2013, 134-135, 40-46. [CrossRef]

31. Anderson, C.G. Treatment of copper ores and concentrates with industrial nitrogen species catalyzed pressure leaching and non-cyanide precious metals recovery. JOM. 2003, 55, 32-36. [CrossRef]

32. Anuario de la Minería de Chile 2016; G.d.C. Sernageomin Ministerio de Minería: Santiago, Chile, 2016.

33. Shiers, D.; Collinson, D.; Kelly, N.; Watling, H. Copper extraction from chalcopyrite: Comparison of three non-sulfate oxidants, hypochlorous acid, sodium chlorate and potassium nitrate, with ferric sulfate. Miner. Eng. 2016, 85, 55-65. [CrossRef]

34. Tsogtkhangai, D.; Mamyachenkov, S.V.; Anisimova, O.S.; Naboichenko, S.S. Kinetics of leaching of copper concentrates by nitric acid. Russ. J. Non-Ferrous Met. 2011, 52, 469-472. [CrossRef]

35. Castellón, C.; Taboada, M.E.; Hernández, P.C. Lixiviación de Concentrado de Calcopirita por Nitrato de Sodio Con Agua de Mar en un Medio Ácido; XXXI Convención Internacional de Minería Acapulco: México, 2015; pp. 227-234.

36. Queneau, P.; Prater, J. Nitric acid process for recovering metal values from sulfide ore materials containing iron sulfides. U.S. Patent 3,793,429, 1974.

37. Arias, J.A. Heap leaching copper ore using sodium nitrate. U.S. Patent US 6.569.391 B1, 2003.

38. Hard, R.A. Process for in-situ mining. US Patent 3.910.636, 1975.

39. Carnahan, T.G.; Heinen, H.J. Chemical mining of copper porphyry ores. US 3.912.330, 1975.

40. Lueders, R.E.; Frankiewicz, T.C. Metal leaching from concentrates using nitrogen dioxide in acids. US 4.189.461, 1980.

41. Anderson, C.G.; Krys, L.E.; Harrison, K.D. Treatment of metal bearing mineral material. US 5.096.486, 1992.

42. Hernández, P.C.; Taboada, M.E.; Herreros, O.O.; Graber, T.A.; Ghorbani, Y. Leaching of chalcopyrite in acidified nitrate using seawater-based media. Minerals 2018, 8, 238. [CrossRef] 
43. Bouffard, S.C. Review of agglomeration practice and fundamentals in heap leaching. Miner. Process. Extr. Metall. Rev. 2005, 26, 233-294. [CrossRef]

44. Schlesinger, M.; King, M.; Sole, K.; Davenport, W. Hydrometallurgical copper extraction: introduction and leaching, In Extractive Metallurgy of Copper; Elsevier: Amsterdam, The Netherlands, 2011; pp. 281-322.

45. Lu, J.; Dreisinger, D.; West-Sells, P. Acid curing and agglomeration for heap leaching. Hydrometallurgy 2017, 167, 30-35. [CrossRef]

46. Herreros, O.; Quiroz, R.; Gutierrez, M. Estimación de equipos de aglomeración en lixiviación en pilas. Innovación 1991, 4, 17-21.

47. Kodali, P.; Depci, T.; Dhawan, N.; Wang, X.; Lin, C.; Miller, J.D. Evaluation of stucco binder for agglomeration in the heap leaching of copper ore. Miner. Eng. 2011, 24, 886-893. [CrossRef]

48. Cerda, C.P.; Taboada, M.E.; Jamett, N.E.; Ghorbani, Y.; Hernández, P.C. Effect of pretreatment on leaching primary copper sulfide in acid-chloride media. Minerals 2017, 8, 1. [CrossRef]

49. Bahamonde, F.; Gómez, M.; Navarro, P. Pre-treatment with sodium chloride and sulfuric acid of a bornitic concentrate and later leaching in chloride solution. In Leaching and Bioleaching of Sulfide Concentrates and Minerals; Hydroprocess-ICMSE 2017: Santiago, Chile, 2017.

50. Taboada, M.E.; Quiroz, R.; Hernández, P.C.; Padilla, A.; Herreros, O.O.; Graber, T.A. Copper ore leaching with pre-treatment. In Innovation, Development and Process Improvement; Hydroprocess ICMSE 2017: Santiago, Chile, 2017; pp. 54-60.

51. Velásquez-Yévenes, L.; Torres, D.; Toro, N. Leaching of chalcopyrite ore agglomerated with high chloride concentration and high curing periods. Hydrometallurgy 2018, 181, 215-220. [CrossRef]

52. Senanayake, G. A review of chloride assisted copper sulfide leaching by oxygenated sulfuric acid and mechanistic considerations. Hydrometallurgy 2009, 98, 21-32. [CrossRef]

53. HSC-Chemistry, version 6; Outokumpu Researcher Oy Antti Roine: Piori, Finland, 2006.

(C) 2019 by the authors. Licensee MDPI, Basel, Switzerland. This article is an open access article distributed under the terms and conditions of the Creative Commons Attribution (CC BY) license (http://creativecommons.org/licenses/by/4.0/). 